\title{
Penerapan Data Mining Untuk Menentukan Pola Penjualan Peralatan Sekolah Pada Brand Wigglo Dengan Menggunakan Algoritma Apriori
}

\author{
*Muhammad Syahril, Kamil Erwansyah, Milfa Yetri \\ Program Studi Sistem Informasi, STMIK Triguna Dharma \\ Jl. A.H Nasution No.73 Medan, Indonesia, 20142 \\ E-mail: m.syahril@trigunadharma.ac.id
}

\begin{abstract}
Abstrak
Penjualan merupakan salah satu kegiatan pemasaran yang cukup penting dalam rangka pencapaian tujuan perusahaan. Pencapaian tingkat penjualan perusahaan adalah salah satu indikator dari tingkat kemajuan perusahaan, untuk mampu mencapai tingkat penjualan yang telah ditargetkan perusahaan itu berarti perusahaan harus mampu menciptakan produk dan jasa yang sesuai dengan kebutuhan dan keinginan konsumen juga bagaimana produk ini menjadi sumber profit bagi perusahaan sebagai fokus perusahaan dalam memasarkan produknya. Banyaknya data transaksi yang disimpan menyebabkan penumpukan data. Data tersebut dapat diolah lebih lanjut menjadi suatu infomasi yang berguna bagi manajer atau pelaku usaha pada PT. Panen Lestari Internusa dalam pengambilan keputusan, melakukan analisis terhadap penjualan pada produknya, mengatur stok serta pola yang ada pada perusahaan tersebut dan melakukan strategi penjualan yang bertujuan untuk kemajuan perusahaan atau usaha tersebutOleh karena itu diperlukan adanya sistem yang dapat membantu dalam menerapkan data penjualan dan transaksi untuk mengatur pola penjualan produk, mengatur stok bahan produk dan menerapkan strategi pemasaran. Algoritma Apriori adalah metode yang sering memanfaatkan itemset dalam pertambangan data atau produk.
\end{abstract}

Kata kunci : Data Mining, Pola Penjualan, Algoritma Apriori

\begin{abstract}
Sales is one of the marketing activities that is quite important in order to achieve company goals. Achieving the level of sales of the company is one indicator of the level of progress of the company, to be able to achieve the level of sales that the company has targeted it means the company must be able to create products and services that are in accordance with the needs and desires of consumers as well as how this product is a source of profit for the company as a focus of the company in marketing their products. The large amount of transaction data stored causes data to accumulate. The data can be further processed into a useful information for managers or business people at PT. Harvest Lestari Internusa in making decisions, analyzing sales of its products, managing stock and patterns that exist in the company and conducting sales strategies aimed at the progress of the company or business. Therefore a system that can help in applying sales and transaction data is needed to help regulate product sales patterns, manage product material stocks and implement marketing strategies. Apriori algorithm is a method that often utilizes itemset in data or product mining.
\end{abstract}

Keywords: Data Mining, Sales Pattern, Apriori Algorithm

\section{PENDAHULUAN}

Perkembangan dan persaingan dalam dunia bisnis perdagangan serta kemajuan 
teknologi informasi merupakan suatu hal yang saling terkait, dalam ketatnya persaingan pasar untuk memenuhi tuntutan pelanggan yang semakin tinggi. Perusahaan memerlukan strategi dan kecerdasan bisnis untuk dapat terus memenuhi keinginan pelanggan dan tuntutan pasar. Sehingga kemajuan teknologi sangat dibutuhkan untuk mengembangkan bisnis perdagangan.

Dalam persaingan di dunia bisnis, khususnya industri di bidang retail, menuntut para pengembang untuk menemukan suatu strategi yang tepat supaya dapat meningkatkan penjualan peralatan sekolah, salah satu cara yaitu dengan mengetahui pola penjualan peralatan sekolah sehingga kita bisa menerapkan langkah-langkah yang tepat untuk memberikan fasilitas yang lebih, guna meningkatkan daya jual.

PT. Panen Lestari Internusa merupakan perusahaan yang bergerak di bidang retail. PT. Panen Lestari Internusa terdiri dari brand ternama, salah satunya adalah Brand Wigglo yang terdiri dari berbagai item jual, seperti Clipboard, Note Book, Note Keyring, Wallet, Pencil Case, Pouch, Bag, Life Style, Sling Bag, Junior Backpack, Eyemask, Duffle Bag, Note Book Canvas, Hardtop Pencil Case, Big Bow, dll. Setiap hari data transaksi penjualan di Brand Wigglo semakin bertambah banyak sehingga data tersebut menumpuk, Namun data ini seringkali diperlakukan hanya sebagai rekaman tanpa pengolahan lebih lanjut sehingga tidak mempunyai nilai guna lebih untuk bisa dimanfaatkan dengan baik. Analisis dari tiap koleksi data tersebut akan menghasilkan pengetahuan atau informasi, misalnya berupa pola dan kaidah asosiasi yang terjadi pada data. Metode yang sering digunakan dalam melakukan menganalisa pola penjualan dalam data mining menerapkan pola penjualan yaitu metode Algoritma Apriori

Algoritma Apriori salah satu dari jenis aturan asosiasi yang ada pada Data Mining, Algoritma Apriori bertujuan untuk menemukan sebuah frequent itemset yang dijalankan pada sekumpulan data. Analisis Apriori adalah suatu proses untuk menemukan semua aturan Apriori yang memenuhi syarat minimum untuk support dan syarat minimum untuk confidence. Penerapan Algoritma Apriori dapat membantu dalam membentuk kandidat kombinasi item, kemudian dilakukan pengujian apakah kombinasi tersebut memenuhi parameter support dan confidence minimum yang merupakan nilai ambang yang diberikan oleh peneliti. Jika memenuhi parameter support dan confidence maka hasil tersebut dapat membantu dalam penentuan pola penjualan peralatan sekolah.

\section{METODE PENELITIAN}

\subsection{Data Mining}

Data yaitu kumpulan fakta yang terekam atau sebuah entitas yang tidak memiliki arti dan selama ini terabaikan. Sedangkan mining yaitu proses penambangan. (Nofriansyah, $2015: 1$ )

Sehingga Data Mining itu dapat diartikan sebagai proses penambangan data yang menghasilkan sebuah output (keluaran) berupa pengetahuan.

Menurut Ristianingrum, dkk (2017 : 372) Data Mining adalah Serangkaian proses untuk menggali nilai tambah berupa informasi yang selama initidak diketahui secara manual dari suatu basisdata dengan melakukan penggalian pola pola dari data dengantujuan untuk memanipulasi data menjadi informasi yang lebih berharga yang diperoleh dengan caramengekstraksi dan mengenali pola yang penting atau menarik dari data yang terdapat dalam basis data.

Data Mining adalah serangkaian proses untuk menambah serta mencari informasi yang selama ini tidak diketahui secara manual dari suatu basis data. Informasi yang dihasilkan diperoleh dengan cara mengekstraksi dan mengenali pola yang penting atau menarik dari data yang terdapat pada basis data. Data mining terutama digunakan untuk mencari pengetahuan yang terdapat dalam basis data yang besar sehingga sering disebut Knowledge Discovery Databases (KDD). (Vulandari, 2017:1-2)

Menurut Larose dalam (Nofriansyah, $2015: 1$ ) 'Data Mining merupakan analisis dari peninjauan kumpulan data untuk menemukan hubungan yang tidak diduga dan meringkas data dengan cara berbeda dengan sebelumnya, yang dapat dipahami dan bermanfaat bagi pemilik data'.

Berdasarkan defenisi-defenisi yang telah disampaikan, hal penting yang terkait dengan Data Mining adalah :

1. Data Mining merupakan suatu proses otomatis terhadap data yang sudah ada.

2. Data yang akan diproses berupa data yang sangat besar.

3. Tujuan Data Mining adalah mendapatkan hubungan atau pola yang mungkin memberikan indikasi yang bermanfaat.

\subsection{Knowledge Discovery Database (KDD)}


Pada proses Data Mining yang biasa disebut Knowledge Discovery Database (KDD). Knowledge Discovery Database (KDD) adalah penerapan metode saintifik pada data mining. Pada konteks ini data mining merupakan satu langkah dari proses KDD, terdapat beberapa proses seperti terlihat pada gambar di bawah ini :

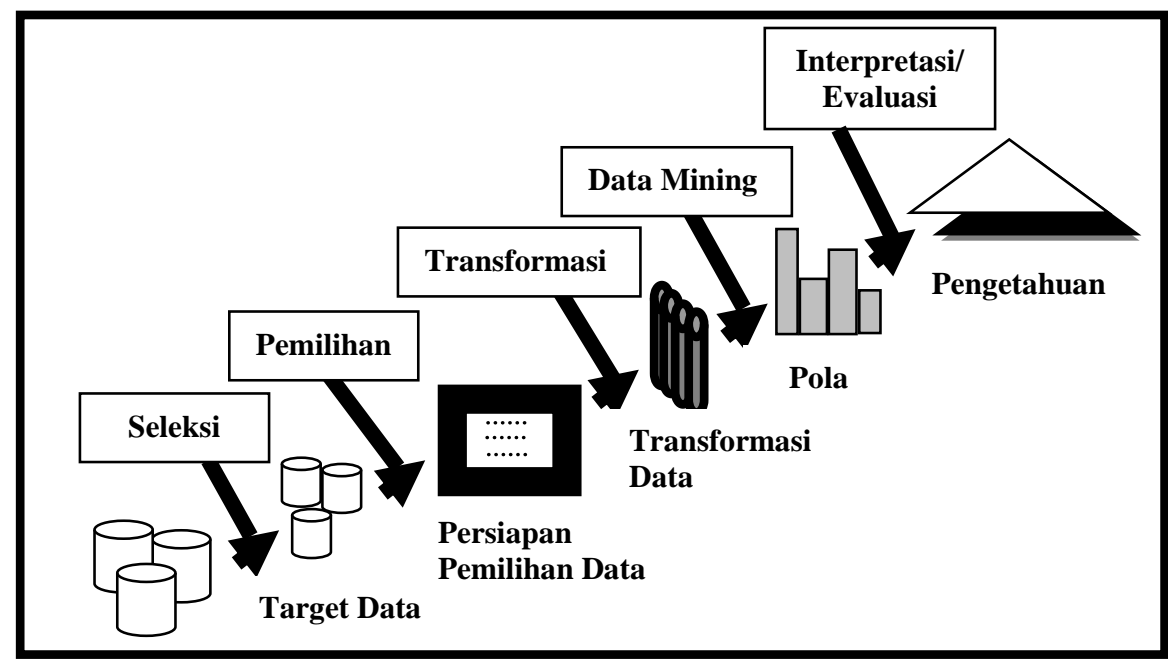

1. Seleksi Data (Selection)

Selection (seleksi/pemilihan) data dari sekumpulan data operasional perlu dilakukan sebelum tahap penggalian informasi dalam Knowledge Discovery Database (KDD) dimulai. Data hasil seleksi yang akan digunakan untuk proses data mining, disimpan dalam suatu berkas, terpisah dari basis data operasional.

2. Pemilihan Data (Preprocessing/Cleaning)

Proses Preprocessing mencakup antara lain membuang duplikasi data, memeriksa data yang inkonsisten, dan memperbaiki kesalahan pada data, seperti kesalahan cetak (tipografi). Juga dilakukan proses enrichment, yaitu proses "memperkaya" data yang sudah ada dengan data atauinformasi lain yang relevan dan diperlukan untuk KDD, seperti data atau informasi eksternal.

3. Transformasi (Transformation)

Pada fase ini yang dilakukan adalah mentransformasi bentuk data yang belum memiliki entitas yang jelas ke dalam bentuk data yang valid atau siap untuk dilakukan proses Data Mining.

4. Data Mining

Pada fase ini yang dilakukan adalah menerapkan algoritma atau metode pencarian pengetahuan.

5. Interpretasi/Evaluasi (Interpratation/Evaluation)

Pada fase terakhir ini yang dilakukan adalah proses pembentukan keluaran yang mudah dimengerti yang bersumber pada proses Data Mining pola informasi.

\subsection{Algoritma Apriori}

Algoritma Apriori adalah salah satu algoritma yang melakukan pencarian frequent itemset dengan menggunakan teknik association rule.

Menurut Ristianingrum, dkk (2017 : 372) Algoritma apriori adalah suatu metode untuk mencari pola hubungan antar satu atau lebih item dalam suatu dataset. Algoritma apriori banyak digunakan pada data transaksi atau biasa disebut market basket,misalnya sebuah swalayan memiliki market basket, dengan adanya algoritma apriori, pemilik swalayan dapat mengetahui pola pembelian seorang konsumen, jika seorang konsumen membeli item A , B, punya kemungkinan $50 \%$ dia akan membeli item C, pola ini sangat signifikan dengan adanya data transaksi selama ini.

Algoritma Apriori menggunakan pengetahuan frekuensi atribut yang telah diketahui sebelumnya untuk memproses informasi selanjutnya. Pada Algoritma Apriori menentukan kandidat yang mungkin

J-SISKO TECH Vol. 3, No. 1, $2020: 118-136$ 
muncul dengan cara memperhatikan minimum support dan minimum confidence. Support adalah nilai pengunjung atau persentase kombinasi sebuah item dalam database

\subsection{Pemodelan Sistem}

Pemodelan sistem adalah proses membangun atau membentuk sebuah model dari suatu sistem nyata dalam bahasa formal tertentu. Untuk memodelkan suatu sistem maka kita perlu tahu gambaran permasalahan yang ada serta hubungan antar komponen.

\subsubsection{Unified Modeling Language (UML)}

"UML (Unified Modeling Language) merupakan bahasa visual untuk pemodelan dan komunikasi mengenai sebuah sistem dengan menggunakan diagram dan teks-teks pendukung". (Rosa \& Shalahuddin, $2015: 137)$.

Pemodelan adalah gambaran dari realita yang simpel dan dituangkan dalam bentuk pemetaan dengan aturan tertentu. Pemodelan dapat menggunakan bentuk yang sama dengan realitas, misalnya jika seorang arsitek ingin memodelkan sebuah gedung yang akan dibangun maka dia akan memodelkannya dengan membuat sebuah maket (tiruan) arsitektur gedung yang akan dibangun dimana maket itu akan dibuat semirip mungkin dengan desain gedung yang akan dibangun agar arsitektur gedung yang diinginkan dapat terlihat. (Rosa \& Shalahuddin, $2015: 135)$

\subsubsection{Use Case Diagram}

Use case atau diagram use case merupakan pemodelan untuk kelakuan (behavior) sistem informasi yang akan dibuat. Use case mendeskripsikan sebuah interaksi antara satu atau lebih aktor dengan sistem informasi yang akan dibuat. Secara kasar, use case digunakan untuk mengetahui fungsi apa saja yang ada di dalam sebuah sistem informasi dan siapa saja yang berhak menggunakan fungsifungsi itu. (Rosa \& Shalahuddin, $2015:$ 155)

\subsubsection{Activity Diagram}

Diagram aktivitas atau activity diagram menggambarkan workflow (aliran kerja) atau aktivitas dari sebuah sistem atau proses bisnis atau menu yang ada pada perangkat lunak.Yang perlu diperhatikan disini adalah bahwa diagram aktivitas menggambarkan aktivitas sistem bukan apa yang dilakukan aktor, jadi aktivitas yang dapat dilakukan oleh sistem. (Rosa \& Shalahuddin, 2015 : 161).

\subsubsection{Class Diagram}

Diagram kelas atau class diagram menggambarkan struktur sistem dari segi pendefinisian kelaskelas yang akan dibuat untuk membangun sistem. Kelas memiliki atribut dan metode atau operasi. (Rosa \& Shalahuddin, $2015:$ 141).

\section{ANALISA DAN HASIL}

\subsection{Analisa Permasalahan}

Proses menentukan pola penjualan pada Toko Bahan Bangunan Utama dilakukan dengan cara menganalisa pola data transaksi penjualan yang didapat dari setiap bulanya, dengan menganalisa sebuah pola yang terkandung didalam data transaksi Toko Bahan Bangunan Utama mendapatkan informasi mengenai produk-produk terunggul atau produk yang paling diminati para konsumenya, dimana hasil informasi tersebut digunakan sebagai acuan untuk tindakan dalam mengembangkan bisnis. Seperti, memperbayak jumlah persediaan produk, dan mengembangkan produk terunggul di setiap bulanya.

Penggunaan alat bantu yang terbatas dan lamanya dalam penentuan produk terunggul Toko Bahan Bangunan Utama menghambat proses penentuan. Sebab semakin bayak data transaksi penjualan dalam kurun waktu tertentu semakin lama juga proses menentukanya, karena proses yang dilakukan masih dilakukan dengan pencatatan, sehingga hal ini membuat pihak perusahaan kesulitan untuk menentukan produk mana yang paling diminati oleh konsumen.

\subsection{Algoritma Sistem}

Algoritma sistem adalah suatu proses sistematika dari pengembangan kebutuhan. Algoritma sistem merupakan cara yang efektif untuk melakukan sesuatu perencanaan pengumpulan data dan analisis data. Adapun tahapan-tahapan algoritma sistem data mining untuk mendapatkan pola belanja produk dengan algoritma apriori pada transaksi penjualan sebagai berikut : 
1. Penginputan data produk dan data transaksi.

2. Pembentukan kombinasi 1 itemset data transaksi.

3. Pembentukan kombinasi 2 itemset data transaksi.

4. Pembentukan aturan asosiasi.

5. Pilih pasangan itemset sesuai dengan nilai minimum support dan minimum confidence yang ditemukan.

Association Rule merupakan suatu proses pada data mining untuk menentukan semua aturan assosiatif yang memenuhi syarat minumun untuk support (minsup) dan confidance (minconf) pada sebuah database. Kedua syarat tersebut akan digunakan untuk interesting association rule dengan dibandingkan dengan batasan yang telah ditentukan, yaitu minsup dan mincof.

Asso ciation Rule Mining adalah suatu prosedur untuk mencari hubungan antar item dalam suatu dataset. Dimulai dengan mencari frequent itemset, yaitu kombinasi yang paling sering terjadi dalam suatu itemset dan harus memenuhi minsup.

Dalam tahap ini akan dilakukan pencarian kombinasi item yang memenuhi syarat minimum dari nilai support dalam database. Untuk mendapatkan nilai support dari suatu item A dapat diperoleh menggunakan rumus berikut :

Support $(A)=\frac{\text { [umlah Transaksi Yang Mlengandung Item } A}{\text { Total Transaksi }}$

Kemudian untuk mendapatkan nilai support dari dua item diperoleh dengan rumus berikut :

Support $(A, B)=\frac{\text { [umlah Transaksi Yang Nengandung Item A dan B }}{\text { Total }}$

Setelah semua frequent item dan large itemset di dapatkan, dapat dicari syarat minum confidence (mincof) dengan menggunakan rumus berikut :

Confidence $(A \rightarrow B)=\frac{\text { [umlah Transaksi MengandungA dan } B}{\text { TotalTranglei }}$

3.3 Hasil Analisis

Berikut adalah sejumlah data produk dari data transaksi pada bulan Oktober 2018 sampai bulan November 2018 pada PT. Panen Lestari Internusa. Data tersebut adalah data sample dari data transaksi sebanyak 40 transaksi yang akan dilakukan pengujiannya :

Tabel 3.1 Data Produk transaksi pada bulan Oktober 2018

\begin{tabular}{|c|c|l|}
\hline No & $\begin{array}{c}\text { Tanggal } \\
\text { Transaksi }\end{array}$ & \multicolumn{1}{c|}{ Transaksi } \\
\hline 1 & $1 / 10 / 2018$ & $\begin{array}{l}\text { Clipboard, Note Book, Note Keyring, Wallet, Pencil Case, Pouch, Life Style, Junior } \\
\text { Backpack, Duffle Bag, Note Book Canvas, Hardtop Pencil Case }\end{array}$ \\
\hline 2 & $2 / 10 / 2018$ & Note Keyring, Life Style, Sling Bag \\
\hline 3 & $4 / 10 / 2018$ & Note Book, Note Keyring, Pencil Case, Pouch, Bag, Note Book Canvas \\
\hline 4 & $6 / 10 / 2018$ & Clipboard, Note Book, Note Keyring, Wallet, Big Bow \\
\hline 5 & $7 / 10 / 2018$ & Note Keyring, Life Style, Sling Bag \\
\hline 6 & $10 / 10 / 2018$ & Note Book, Note Keyring, Pencil Case, Pouch, Bag, Sling Bag \\
\hline 7 & $12 / 10 / 2018$ & Clipboard, Note Book, Bag, Sling Bag, Eyemask, Hardtop Pencil Case \\
\hline 8 & $13 / 10 / 2018$ & Clipboard, Bag, Life Style, Sling Bag, Junior Backpack \\
\hline 9 & $14 / 10 / 2018$ & $\begin{array}{l}\text { Clipboard, Note Book, Note Keyring, Pencil Case, Pouch, Bag, Sling Bag, Junior } \\
\text { Backpack, Note Book Canvas, Hardtop Pencil Case }\end{array}$ \\
\hline 10 & $16 / 10 / 2018$ & Clipboard, Wallet, Pencil Case, Bag, Junior Backpack, Eyemask \\
\hline 11 & $18 / 10 / 2018$ & $\begin{array}{l}\text { Clipboard, Note Book, Note Keyring, Wallet, Pouch, Bag, Life Style, Hardtop } \\
\text { Pencil Case }\end{array}$ \\
\hline
\end{tabular}

J-SISKO TECH Vol. 3, No. 1, $2020: 118-136$ 
\begin{tabular}{l|l|l|l}
12 & $20 / 10 / 2018$ & Note Book, Note Keyring, Pencil Case, Pouch, Bag, Junior Backpack
\end{tabular}

Tabel 3.1 Data Produk transaksi pada bulan Oktober 2018 (Lanjutan)

\begin{tabular}{|c|c|c|}
\hline No & $\begin{array}{c}\text { Tanggal } \\
\text { Transaksi }\end{array}$ & Transaksi \\
\hline 13 & $21 / 10 / 2018$ & Duffle Bag, Hardtop Pencil Case \\
\hline 14 & $24 / 10 / 2018$ & Clipboard, Note Keyring, Big Bow \\
\hline 5 & $25 / 10 / 2018$ & Life Style, Sling Bag, Hardtop Pencil Case \\
\hline 16 & $27 / 10 / 2018$ & Clipboard, Note Book, Pencil Case, Pouch, Bag, Eyemask, Note Book Canvas \\
\hline 17 & $28 / 10 / 2018$ & Duffle Bag \\
\hline 18 & $30 / 10 / 2018$ & Clipboard, Wallet, Life Style, Hardtop Pencil Case \\
\hline 19 & $31 / 10 / 2018$ & Pouch, Bag, Big Bow \\
\hline 20 & $2 / 11 / 2018$ & Clipboard, Note Book, Wallet, Pencil Case, Sling Bag, Note Book Canvas \\
\hline 21 & $3 / 11 / 2018$ & Note Book, Note Keyring, Pouch, Life Style, Junior Backpack, Eyemask \\
\hline 22 & $4 / 11 / 2018$ & Clipboard, Wallet, Pencil Case, Bag, Junior Backpack \\
\hline 23 & $6 / 11 / 2018$ & Clipboard, Note Book, Sling Bag, Junior Backpack, Big Bow \\
\hline 24 & $7 / 11 / 2018$ & Clipboard, Junior Backpack, Duffle Bag \\
\hline 25 & $10 / 11 / 2018$ & $\begin{array}{l}\text { Clipboard, Note Book, Wallet, Pencil Case, Bag, Sling Bag, Junior Backpack, Note } \\
\text { Book Canvas }\end{array}$ \\
\hline 26 & $11 / 11 / 2018$ & Clipboard, Pouch, Bag, Life Style, Sling Bag, Note Book Canvas \\
\hline 27 & $13 / 11 / 2018$ & Note Book, Note Keyring, Pouch, Bag, Hardtop Pencil Case \\
\hline 28 & $15 / 11 / 2018$ & Bag \\
\hline 29 & $16 / 11 / 2018$ & Clipboard, Note Book, Wallet, Pencil Case, Bag \\
\hline 30 & $17 / 11 / 2018$ & Bag, Life Style, Sling Bag, Note Book Canvas, Hardtop Pencil Case \\
\hline 31 & $18 / 11 / 2018$ & Note Keyring, Pencil Case \\
\hline 32 & $20 / 11 / 2018$ & Clipboard, Pencil Case, Bag, Sling Bag, Junior Backpack, Eyemask \\
\hline 33 & $23 / 11 / 2018$ & Note Book, Pencil Case, Junior Backpack, Duffle Bag, Hardtop Pencil Case \\
\hline 34 & $24 / 11 / 2018$ & Life Style, Junior Backpack \\
\hline 35 & $25 / 11 / 2018$ & Clipboard, Wallet, Pencil Case, Pouch, Bag, Junior Backpack \\
\hline 36 & $26 / 11 / 2018$ & Note Book, Note Keyring \\
\hline 37 & $27 / 11 / 2018$ & Duffle Bag \\
\hline 38 & $28 / 11 / 2018$ & Clipboard, Note Book, Pencil Case, Sling Bag, Junior Backpack \\
\hline
\end{tabular}




\begin{tabular}{|l|l|l|}
39 & $29 / 11 / 2018$ & Life Style \\
\hline 40 & $30 / 11 / 2018$ & Clipboard, Note Book, Pencil Case, Pouch, Sling Bag \\
\hline
\end{tabular}

\subsubsection{Menentukan Support 1 Itemset}

Dari data transkasi pada tabel 3.1, maka dapat dicari nilai support1 itemset dengan rumus sebagai berikut :

$$
\text { Support }(A)=\frac{\text { jumlah transaksi mengandung A }}{\text { total transaksi }} \times 100 \%
$$

Sehingga dapat dicari nilai support 1 itemset seperti pada tabel dibawah ini. Dari perhitungan diatas dapat dibuat tabel untuk mempermudah melihat nilai support 1 itemset, berikut tabelnya :

Tabel 3.2 : Hasil Support 1 Itemset

\begin{tabular}{|c|l|c|c|}
\hline No & \multicolumn{1}{|c|}{ Itemset } & $\begin{array}{c}\text { Frekuensi } \\
\text { Kemunculan }\end{array}$ & Support 1 Itemset \\
\hline 1 & Clipboard & 21 & $\frac{21}{40} \times 100 \%=52,50 \%$ \\
\hline 2 & Note Book & 19 & $\frac{19}{40} \times 100 \%=47,50 \%$ \\
\hline 3 & Note Keyring & 14 & $\frac{14}{40} \times 100 \%=35,00 \%$ \\
\hline 4 & Wallet & 10 & $\frac{10}{40} \times 100 \%=25,00 \%$ \\
\hline 5 & Pensil Case & 17 & $\frac{17}{40} \times 100 \%=42,50 \%$ \\
\hline 6 & Pouch & 13 & $\frac{13}{40} \times 100 \%=32,50 \%$ \\
\hline 7 & Bag & 19 & $\frac{19}{40} \times 100 \%=47,50 \%$ \\
\hline 8 & Life Style & 12 & $\frac{12}{40} \times 100 \%=30,00 \%$ \\
\hline 9 & Sling Bag & 15 & $\frac{15}{40} \times 100 \%=37,50 \%$ \\
\hline 10 & Junior Backack & 15 & $\frac{15}{40} \times 100 \%=37,50 \%$ \\
\hline 11 & Eyemask & 5 & $\frac{5}{40} \times 100 \%=12,50 \%$ \\
\hline 12 & Duffle Bag & 6 & $\frac{6}{40} \times 100 \%=15,00 \%$ \\
\hline 13 & Note Book Canvas & 8 & $\frac{8}{40} \times 100 \%=20,00 \%$ \\
\hline 14 & Hardtop Pencil Case & 10 & $\frac{10}{40} \times 100 \%=25,00 \%$ \\
\hline 15 & Big Bow & 4 & $\frac{4}{40} \times 100 \%=10,00 \%$ \\
\hline
\end{tabular}

Dengan nilai support yang didapat, maka ditentukan minimum support sebesar $25 \%$, kemudian eliminasi nilai support 1 itemset yang tidak memenuhi ketentuan minimum support yaitu sebagai berikut :

J-SISKO TECH Vol. 3, No. 1, $2020: 118-136$ 
Tabel 3.3 Hasil Minimum Support 1 Itemset

\begin{tabular}{|c|l|c|c|}
\hline No & \multicolumn{1}{|c|}{ Itemset } & $\begin{array}{c}\text { Frekuensi } \\
\text { Kemunculan }\end{array}$ & $\begin{array}{c}\text { Support 1 } \\
\text { Itemset }\end{array}$ \\
\hline 1 & Clipboard & 21 & $52,50 \%$ \\
\hline 2 & Note Book & 19 & $47,50 \%$ \\
\hline 3 & Note Keyring & 14 & $35,00 \%$ \\
\hline 4 & Wallet & 10 & $25,00 \%$ \\
\hline 5 & Pensil Case & 17 & $42,50 \%$ \\
\hline
\end{tabular}

Tabel 3.3 Hasil Minimum Support 1 Itemset (Lanjutan)

\begin{tabular}{|c|l|c|c|}
\hline No & \multicolumn{1}{|c|}{ Itemset } & $\begin{array}{c}\text { Frekuensi } \\
\text { Kemunculan }\end{array}$ & $\begin{array}{c}\text { Support 1 } \\
\text { Itemset }\end{array}$ \\
\hline 6 & Pouch & 13 & $32,50 \%$ \\
\hline 7 & Bag & 19 & $47,50 \%$ \\
\hline 8 & Life Style & 12 & $30,00 \%$ \\
\hline 9 & Sling Bag & 15 & $37,50 \%$ \\
\hline 10 & Junior Backpack & 15 & $37,50 \%$ \\
\hline 11 & Hardtop Pencil Case & 10 & $25,00 \%$ \\
\hline
\end{tabular}

\subsubsection{Menentukan Support 2 Itemset}

Dari data transaksi pada tabel 3.2 dan hasil minimum support 1 itemset pada tabel 3.4, maka dapat dicari nilai support2 itemset dengan rumus sebagai berikut :

$$
\text { Support }=\frac{\Sigma \text { transaksi mengandung } \mathrm{A} \text { danB }}{\text { total transaksi }} \times 100 \%
$$

Sehingga dapat dicari nilai support 2 itemset pada tabel dibawah ini :

Tabel 3.4 : Hasil Nilai Support 2 Itemset

\begin{tabular}{|c|l|c|c|}
\hline No & \multicolumn{1}{|c|}{ Itemset } & $\begin{array}{c}\text { Frekuensi } \\
\text { Kemunculan }\end{array}$ & Support 2 Itemset \\
\hline 1 & Clipboard, Note Book & 12 & $\frac{12}{40} \times 100 \%=30,00 \%$ \\
\hline 2 & Clipboard, Note Keyring & 5 & $\frac{5}{40} \times 100 \%=12,50 \%$ \\
\hline 3 & Clipboard, Wallet & 10 & $\frac{10}{40} \times 100 \%=25,00 \%$ \\
\hline 4 & Clipboard, Pencil Case & 12 & $\frac{12}{40} \times 100 \%=30,00 \%$ \\
\hline
\end{tabular}




\begin{tabular}{|c|l|c|c|}
5 & Clipboard, Pouch & 7 & $\frac{7}{40} \times 100 \%=17,50 \%$ \\
\hline 6 & Clipboard, Bag & 12 & $\frac{12}{40} \times 100 \%=30,00 \%$ \\
\hline 7 & Clipboard, Life Style & 5 & $\frac{5}{40} \times 100 \%=12,50 \%$ \\
\hline 8 & Clipboard, Sling Bag & 10 & $\frac{10}{40} \times 100 \%=25,00 \%$ \\
\hline
\end{tabular}

Tabel 3.4 : Hasil Nilai Support 2 Itemset (Lanjutan)

\begin{tabular}{|c|c|c|c|}
\hline No & Itemset & $\begin{array}{c}\text { Frekuensi } \\
\text { Kemunculan }\end{array}$ & Support 2 Itemset \\
\hline 9 & Clipboard, Junior Backpack & 11 & $\frac{11}{40} \times 100 \%=27,50 \%$ \\
\hline 10 & Clipboard, Hardtop Pencil Case & 5 & $\frac{5}{40} \times 100 \%=12,50 \%$ \\
\hline 11 & Note Book, Note Keyring & 10 & $\frac{10}{40} \times 100 \%=25,00 \%$ \\
\hline 12 & Note Book, Wallet & 6 & $\frac{6}{40} \times 100 \%=15,00 \%$ \\
\hline 13 & Note Book, Pencil Case & 12 & $\frac{12}{40} \times 100 \%=30,00 \%$ \\
\hline 14 & Note Book, Pouch & 10 & $\frac{10}{40} \times 100 \%=25,00 \%$ \\
\hline 15 & Note Book, Bag & 10 & $\frac{10}{40} \times 100 \%=25,00 \%$ \\
\hline 16 & Note Book, Life Style & 3 & $\frac{a}{40} \times 100 \%=7,50 \%$ \\
\hline 17 & Note Book, Sling Bag & 8 & $\frac{8}{40} \times 100 \%=20,00 \%$ \\
\hline 18 & Note Book, Junior Backpack & 8 & $\frac{8}{40} \times 100 \%=20,00 \%$ \\
\hline 19 & Note Book, Hardtop Pencil Case & 6 & $\frac{6}{40} \times 100 \%=15,00 \%$ \\
\hline 20 & Note Keyring, Wallet & 3 & $\frac{3}{40} \times 100 \%=7,50 \%$ \\
\hline 21 & Note Keyring, Pencil Case & 6 & $\frac{6}{40} \times 100 \%=15,00 \%$ \\
\hline 22 & Note Keyring, Pouch & 8 & $\frac{8}{40} \times 100 \%=20,00 \%$ \\
\hline 23 & Note Keyring, Bag & 5 & $\frac{5}{40} \times 100 \%=12,50 \%$ \\
\hline 24 & Note Keyring, Life Style & 5 & $\frac{5}{40} \times 100 \%=12,50 \%$ \\
\hline 25 & Note Keyring, Sling Bag & 4 & $\frac{4}{40} \times 100 \%=10,00 \%$ \\
\hline
\end{tabular}

J-SISKO TECH Vol. 3, No. 1, $2020: 118-136$ 


\begin{tabular}{|c|l|c|c|}
\hline 26 & Note Keyring, Junior Backpack & 4 & $\frac{4}{40} \times 100 \%=10,00 \%$ \\
\hline 27 & Note Keyring, Hardtop Pencil Case & 4 & $\frac{4}{40} \times 100 \%=10,00 \%$ \\
\hline 28 & Wallet, Pencil Case & 7 & $\frac{7}{40} \times 100 \%=17,50 \%$ \\
\hline 29 & Wallet, Pouch & 3 & $\frac{3}{40} \times 100 \%=7,50 \%$ \\
\hline
\end{tabular}

Tabel 3.4 : Hasil Nilai Support 2 Itemset (Lanjutan)

\begin{tabular}{|c|c|c|c|}
\hline No & Itemset & $\begin{array}{c}\text { Frekuensi } \\
\text { Kemunculan }\end{array}$ & Support 2 Itemset \\
\hline 30 & Wallet, Bag & 6 & $\frac{6}{40} \times 100 \%=15,00 \%$ \\
\hline 31 & Wallet, LifeStyle & 3 & $\frac{a}{40} \times 100 \%=7,50 \%$ \\
\hline 32 & Wallet, Sling Bag & 2 & $\frac{2}{40} \times 100 \%=5,00 \%$ \\
\hline 33 & Wallet, Junior Backpack & 5 & $\frac{5}{40} \times 100 \%=12,50 \%$ \\
\hline 34 & Wallet, Hardtop Pencil Case & 3 & $\frac{a}{40} \times 100 \%=7,50 \%$ \\
\hline 35 & Pencil Case, Pouch & 8 & $\frac{8}{40} \times 100 \%=20,00 \%$ \\
\hline 36 & Pencil Case, Bag & 11 & $\frac{11}{40} \times 100 \%=27,50 \%$ \\
\hline 37 & Pencil Case, Life Style & 1 & $\frac{1}{40} \times 100 \%=2,50 \%$ \\
\hline 38 & Pencil Case, Sling Bag & 7 & $\frac{7}{40} \times 100 \%=17,50 \%$ \\
\hline 39 & Pencil Case, Junior Backpack & 10 & $\frac{10}{40} \times 100 \%=25,00 \%$ \\
\hline 40 & Pencil Case, Hardtop Pencil Case & 3 & $\frac{a}{40} \times 100 \%=7,50 \%$ \\
\hline 41 & Pouch, Bag & 10 & $\frac{10}{40} \times 100 \%=25,00 \%$ \\
\hline 42 & Pouch, Life Style & 4 & $\frac{4}{40} \times 100 \%=10,00 \%$ \\
\hline 43 & Pouch, Sling Bag & 4 & $\frac{4}{40} \times 100 \%=10,00 \%$ \\
\hline 44 & Pouch, Junior Backpack & 5 & $\frac{5}{40} \times 100 \%=12,50 \%$ \\
\hline 45 & Pouch, Hardtop Pencil Case & 4 & $\frac{4}{40} \times 100 \%=10,00 \%$ \\
\hline 46 & Bag, Life Style & 4 & $\frac{4}{40} \times 100 \%=10,00 \%$ \\
\hline 47 & Bag, Sling Bag & 8 & $\frac{8}{40} \times 100 \%=20,00 \%$ \\
\hline
\end{tabular}




\begin{tabular}{|c|l|c|c|}
\hline 48 & Bag, Junior Backpack & 8 & $\frac{8}{40} \times 100 \%=20,00 \%$ \\
\hline 49 & Bag, Hardtop Pencil Case & 5 & $\frac{5}{40} \times 100 \%=12,50 \%$ \\
\hline 50 & Life Style, Sling Bag & 6 & $\frac{6}{40} \times 100 \%=15,00 \%$ \\
\hline 51 & Life Style, Junior Backpack & 4 & $\frac{4}{40} \times 100 \%=10,00 \%$ \\
\hline
\end{tabular}

Tabel 3.4 : Hasil Nilai Support 2 Itemset (Lanjutan)

\begin{tabular}{|c|l|c|c|}
\hline No & Itemset & $\begin{array}{c}\text { Frekuensi } \\
\text { Kemunculan }\end{array}$ & Support 2 Itemset \\
\hline 52 & Life Style,Hardtop Pencil Case & 5 & $\frac{5}{40} \times 100 \%=12,50 \%$ \\
\hline 53 & Sling Bag, Junior Backpack & 6 & $\frac{6}{40} \times 100 \%=15,00 \%$ \\
\hline 54 & Sling Bag, Hardtop Pencil Case & 3 & $\frac{\mathrm{a}}{40} \times 100 \%=7,50 \%$ \\
\hline 55 & Junior Backpack, Hardtop Pencil Case & 3 & $\frac{\mathrm{a}}{40} \times 100 \%=7,50 \%$ \\
\hline
\end{tabular}

Dengan nilai support 2 itemset yang didapat, maka ditentukan minimum support sebesar $25 \%$, kemudian eliminasi nilai support 2 itemset yang tidak memenuhi ketentuan minimum support yaitu sebagai berikut :

Tabel 3.5 : Hasil Minimum Support 2 Itemset

\begin{tabular}{|c|l|c|c|}
\hline NO & \multicolumn{1}{|c|}{ Itemset } & $\begin{array}{c}\text { Frekuensi } \\
\text { Kemunculan }\end{array}$ & $\begin{array}{c}\text { Support 2 } \\
\text { Itemset }\end{array}$ \\
\hline 1 & Clipboard, Note Book & 12 & $30,00 \%$ \\
\hline 2 & Clipboard, Wallet & 10 & $25,00 \%$ \\
\hline 3 & Clipboard, Pencil Case & 12 & $30,00 \%$ \\
\hline 4 & Clipboard, Bag & 12 & $30,00 \%$ \\
\hline 5 & Clipboard, Sling Bag & 10 & $25,00 \%$ \\
\hline 6 & Clipboard, Junior Backpack & 11 & $27,50 \%$ \\
\hline 7 & Note Book, Note Keyring & 10 & $25,00 \%$ \\
\hline 8 & Note Book, Pencil Case & 12 & $30,00 \%$ \\
\hline 9 & Note Book, Pouch & 10 & $25,00 \%$ \\
\hline 10 & Note Book, Bag & 10 & $25,00 \%$ \\
\hline 11 & Pencil Case, Bag & 11 & $27,50 \%$ \\
\hline 12 & Pencil Case, Junior Backpack & 10 & $25,00 \%$ \\
\hline 13 & Pouch, Bag & 10 & $25,00 \%$ \\
\hline
\end{tabular}

\subsubsection{Menentukan Confidence}

Selanjutnya akan dihitung nilai confidence. Nilai confidence ditentukan dari setiap kombinasiyang terdapat pada tabel 3.5 berdasarkan rumus :

J-SISKO TECH Vol. 3, No. 1, 2020:118-136 
Confidence $=\frac{\Sigma \text { Transaksi mengandung A dan } \mathrm{B}}{\Sigma \text { Transaksi mengandung A }} \times 100 \%$

Sehingga dapat dicari nilai confidence sepertipada tabel dibawah ini :

Tabel 3.6: Hasil Confidence

\begin{tabular}{|c|c|c|c|c|}
\hline No & Itemset & $\begin{array}{c}\text { Frekuensi } \\
\text { Kemunculan A }\end{array}$ & $\begin{array}{c}\text { Frekuensi } \\
\text { Kemunculan } \\
A \cap B\end{array}$ & Confidence \\
\hline 1 & Clipboard, Note Book & 21 & 12 & $\frac{12}{21} \times 100 \%=57,14 \%$ \\
\hline 2 & Note Book, Clipboard & 19 & 12 & $\frac{12}{19} \times 100 \%=63,15 \%$ \\
\hline 3 & Clipboard, Wallet & 21 & 10 & $\frac{10}{21} \times 100 \%=47,61 \%$ \\
\hline 4 & Wallet, Clipboard & 10 & 10 & $\frac{10}{10} \times 100 \%=100 \%$ \\
\hline 5 & Clipboard, Pencil Case & 21 & 12 & $\frac{12}{21} \times 100 \%=57,14 \%$ \\
\hline 6 & Pencil Case, Clipboard & 17 & 12 & $\frac{12}{17} \times 100 \%=70,58 \%$ \\
\hline 7 & Clipboard, Bag & 21 & 12 & $\frac{12}{21} \times 100 \%=57,14 \%$ \\
\hline 8 & Bag, Clipboard & 19 & 12 & $\frac{12}{19} \times 100 \%=63,15 \%$ \\
\hline 9 & Clipboard, Sling Bag & 21 & 10 & $\frac{10}{21} \times 100 \%=47,61 \%$ \\
\hline 10 & Sling Bag, Clipboard & 15 & 10 & $\frac{10}{15} \times 100 \%=66,66 \%$ \\
\hline 11 & Clipboard, Junior Backpack & 21 & 11 & $\frac{11}{21} \times 100 \%=52,38 \%$ \\
\hline 12 & Junior Backpack, Clipboard & 15 & 11 & $\frac{11}{15} \times 100 \%=73,33 \%$ \\
\hline 13 & Note Book, Note Keyring & 19 & 10 & $\frac{10}{19} \times 100 \%=52,63 \%$ \\
\hline 14 & Note Keyring, Note Book & 14 & 10 & $\frac{10}{14} \times 100 \%=71,42 \%$ \\
\hline 15 & Note Book, Pencil Case & 19 & 12 & $\frac{12}{19} \times 100 \%=63,15 \%$ \\
\hline
\end{tabular}




\begin{tabular}{|c|l|c|c|c|}
\hline 16 & Pencil Case, Notebook & 17 & 12 & $\frac{12}{17} \times 100 \%=70,58 \%$ \\
\hline 17 & Note Book, Pouch & 19 & 10 & $\frac{10}{19} \times 100 \%=52,63 \%$ \\
\hline 18 & Pouch, Note Book & 13 & 10 & $\frac{10}{13} \times 100 \%=76,92 \%$ \\
\hline 19 & Note Book, Bag & 19 & 10 & $\frac{10}{19} \times 100 \%=52,63 \%$ \\
\hline
\end{tabular}

Tabel 3.6 : Hasil Confidence (Lanjutan)

\begin{tabular}{|c|c|c|c|c|}
\hline No & Itemset & $\begin{array}{c}\text { Frekuensi } \\
\text { Kemunculan A }\end{array}$ & 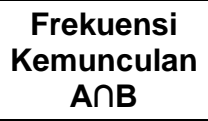 & Confidence \\
\hline 20 & Bag, Note Book & 19 & 10 & $\frac{10}{19} \times 100 \%=52,63 \%$ \\
\hline 21 & Pencil Case, Bag & 17 & 11 & $\frac{11}{17} \times 100 \%=64,70 \%$ \\
\hline 22 & Bag, Pencil Case & 19 & 11 & $\frac{11}{19} \times 100 \%=57,89 \%$ \\
\hline 23 & Pencil Case, Junior Backpack & 17 & 10 & $\frac{10}{17} \times 100 \%=58,82 \%$ \\
\hline 24 & Junior Backpack, Pencil Case & 15 & 10 & $\frac{10}{15} \times 100 \%=66,66 \%$ \\
\hline 25 & Pouch, Bag & 13 & 10 & $\frac{10}{13} \times 100 \%=76,92 \%$ \\
\hline 26 & Bag, Pouch & 19 & 10 & $\frac{10}{19} \times 100 \%=52,63 \%$ \\
\hline
\end{tabular}

Dengan nilai confidence yang didapat, maka ditentukan minimum ceonfidence sebesar $55 \%$, kemudian eliminasi nilai confidence yang tidak memenuhi ketentuan minimum confidence yaitu sebagai berikut :

Tabel 3.7 : Hasil Minimum Confidence

\begin{tabular}{|c|c|c|c|c|}
\hline No & Itemset & $\begin{array}{c}\text { Frekuensi } \\
\text { Kemunculan A }\end{array}$ & $\begin{array}{c}\text { Frekuensi } \\
\text { Kemunculan } \\
\text { AnB }\end{array}$ & Confidence \\
\hline 1 & Clipboard, Note Book & 21 & 12 & $57,14 \%$ \\
\hline 2 & Note Book, Clipboard & 19 & 12 & $63,15 \%$ \\
\hline 3 & Wallet, Clipboard & 10 & 10 & $100 \%$ \\
\hline 4 & Clipboard, Pencil Case & 21 & 12 & $57,14 \%$ \\
\hline 5 & Pencil Case, Clipboard & 17 & 12 & $70,58 \%$ \\
\hline 6 & Clipboard, Bag & 21 & 12 & $57,14 \%$ \\
\hline
\end{tabular}

J-SISKO TECH Vol. 3, No. 1, 2020: 118-136 


\begin{tabular}{|c|c|c|c|c|}
\hline 7 & Bag, Clipboard & 19 & 12 & $63,15 \%$ \\
\hline 8 & Sling Bag, Clipboard & 15 & 10 & $66,66 \%$ \\
\hline 9 & Junior Backpack, Clipboard & 15 & 11 & $73,33 \%$ \\
\hline 10 & Note Keyring, Note Book & 14 & 10 & $71,42 \%$ \\
\hline 11 & Note Book, Pencil Case & 19 & 12 & $63,15 \%$ \\
\hline
\end{tabular}

Tabel 3.7 : Hasil Minimum Confidence (Lanjutan)

\begin{tabular}{|c|c|c|c|c|}
\hline 12 & Pencil Case, Notebook & 17 & 12 & $70,58 \%$ \\
\hline 13 & Pouch, Note Book & 13 & 10 & $76,92 \%$ \\
\hline 14 & Pencil Case, Bag & 17 & 11 & $64,70 \%$ \\
\hline 15 & Bag, Pencil Case & 19 & 11 & $57,89 \%$ \\
\hline 16 & Pencil Case, Junior Backpack & 17 & 10 & $58,82 \%$ \\
\hline 17 & Junior Backpack, Pencil Case & 15 & 10 & $66,66 \%$ \\
\hline 18 & Pouch, Bag & 13 & 10 & $76,92 \%$ \\
\hline
\end{tabular}

\subsubsection{Pembentukan Aturan Asosiasi}

Setelah mendapatkan nilai support dan confidence yang telah memenuhi pola kombinasi 2 itemset, dengan ketentuan minimum support $=25 \%$ dan minimum confidence $55 \%$ maka aturan asosiasi yang terbentuk adalah sebagai berikut :

Tabel 3.8 : Aturan Asosiasi Yang Terbentuk

\begin{tabular}{|c|c|c|c|}
\hline No & Itemset & Support & Confidence \\
\hline 1 & Clipboard, Note Book & $30,00 \%$ & $57,14 \%$ \\
\hline 2 & Note Book, Clipboard & $30,00 \%$ & $63,15 \%$ \\
\hline 3 & Wallet, Clipboard & $25,00 \%$ & $100 \%$ \\
\hline 4 & Clipboard, Pencil Case & $30,00 \%$ & $57,14 \%$ \\
\hline 5 & Pencil Case, Clipboard & $30,00 \%$ & $70,58 \%$ \\
\hline 7 & Clipboard, Bag & $30,00 \%$ & $57,14 \%$ \\
\hline 8 & Bag, Clipboard & $30,00 \%$ & $63,15 \%$ \\
\hline 10 & Sling Bag, Clipboard & $25,00 \%$ & $66,66 \%$ \\
\hline
\end{tabular}




\begin{tabular}{|c|c|c|c|}
\hline 11 & Note Book, Pencil Case & $30,00 \%$ & $63,15 \%$ \\
\hline 12 & Pencil Case, Notebook & $30,00 \%$ & $70,58 \%$ \\
\hline 13 & Pouch, Note Book & $25,00 \%$ & $76,92 \%$ \\
\hline 14 & Pencil Case, Bag & $27,50 \%$ & $64,70 \%$ \\
\hline 15 & Bag, Pencil Case & $27,50 \%$ & $57,89 \%$ \\
\hline 16 & Pencil Case, Junior Backpack & $25,00 \%$ & $58,82 \%$ \\
\hline 17 & Junior Backpack, Pencil Case & $25,00 \%$ & $66,66 \%$ \\
\hline 18 & Pouch, Bag & $25,00 \%$ & $76,92 \%$ \\
\hline
\end{tabular}

\section{IMPLEMENTASI DAN PENGUJIAN}

\subsection{Kebutuhan Sistem}

Setelah analisis perancangan aplikasi selesai maka tahapan selanjutnya adalah implementasi dari rancangan tersebut sekaligus menguji kinerja dari sistem yang telah dirancang. Aplikasi Penerapan Data Mining untuk menentukan pola penjualan peralatan sekolah dengan menggunakan Algoritma Apriori ini membutuhkan perangkat keras ( $h a r d w a r e)$ untuk mengimplementasikan sistem agar berjalan dengan baik, spesifikasinya adalah sebagai berikut :

1. Komputer atau laptop dengan processor mulai dari Core 2

2. Memory dengan kapasitas minimal $2 \mathrm{~GB}$

3. Harddisk minimal $320 \mathrm{~GB}$

Sedangkan perangkat lunak yang dibutuhkan untuk menjalankan aplikasi Data Mining ini adalah sebagai berikut:

1. Sistem Operasi Windows

2. Microsoft Visual Studio 2008

3. . Netframework 3.5

4. Microsoft Access 2007

5. Microsoft Excel 2007

\subsection{Implementasi Sistem}

Implementasi sistem adalah tahapan dimana sistem atau aplikasi siap untuk dioperasikan pada keadaan yang Implementasi sistem adalah tahapan dimana sistem atau aplikasi siap untuk dioperasikan pada keadaan yang sebenarnya sesuai dari hasil analisis dan perancangan yang dilakukan, sehingga akan diketahui apakah sistem atau aplikasi yang dirancang benar-benar dapat menghasilkan tujuan yang dicapai.

Aplikasi Data Mining ini dilengkapi dengan tampilan yang bertujuan untuk memudahkan penggunanya. Fungsi dari antaramuka ini adalah untuk memberikan input dan menampilkan output dari aplikasi. Pada aplikasi ini memiliki interface yang terdiri dari Form Login, Form Menu Utama, Form Data Barang, Form Data Transaksi, Form Kombinasi Item, Form Proses Algoritma Apriori dan Form Rancangan Laporan.

\section{Form Login}

Form Login digunakan untuk mengamankan sistem dari user-user yang tidak bertanggung jawab sebelum masuk ke Menu Utama. Berikut adalah tampilan Form Login : 


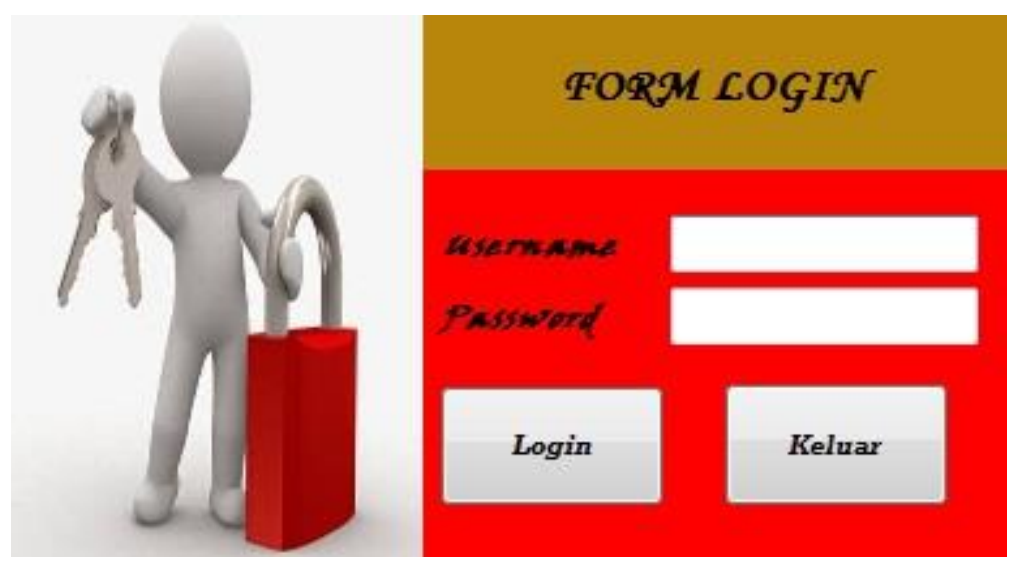

Gambar 4.1 Form Login

2. Form Menu Utama

Form Menu Utama digunakan sebagai penghubung untuk Form Data Barang, Form Data Transaksi, Form Proses Algoritma Apriori, dan Form Laporan. Selain itu, ada beberapa menu lainnya salah satunya ada sub menu Keluar pada bagian menu File bertujuan untuk mengakhiri program secara keseluruhan.

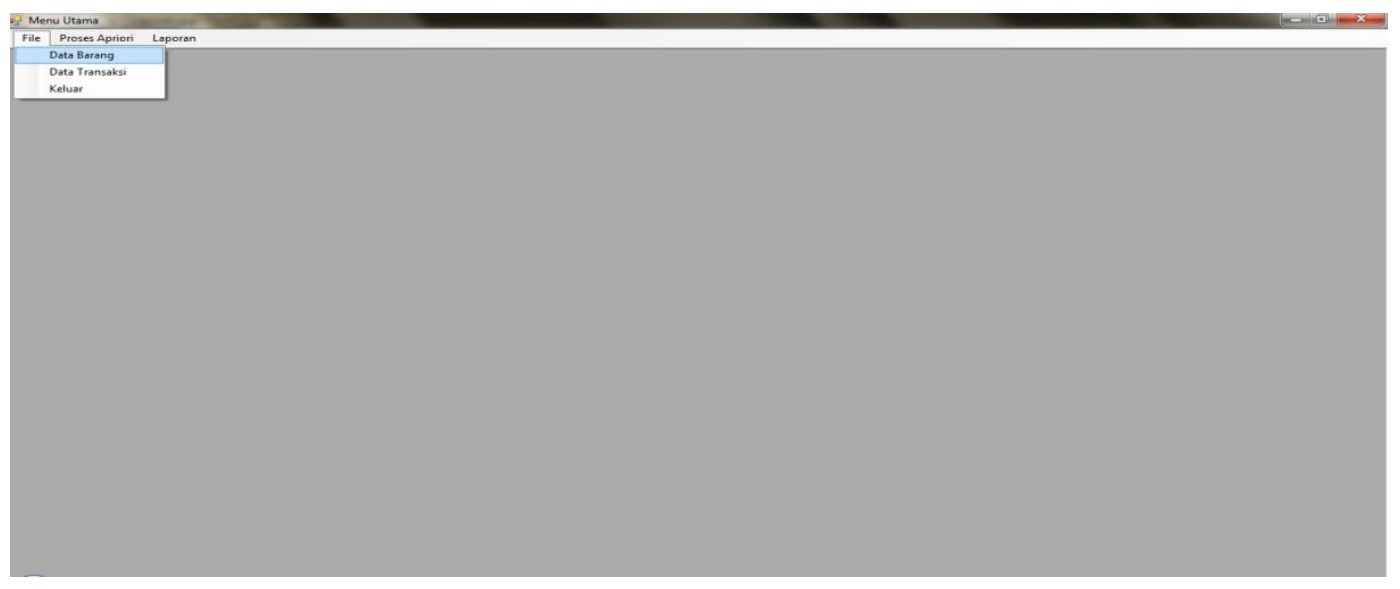

Gambar 4.2 Form Menu Utama

\section{Form Data Barang}

Form Data Barang adalah Form yang berfungsi untuk mengelola data penjualan peralatan sekolah pada Brand Wigglo. Pada Form ini, user dapat menginputkan barang baru atau menghapus serta mengubah data barang. 


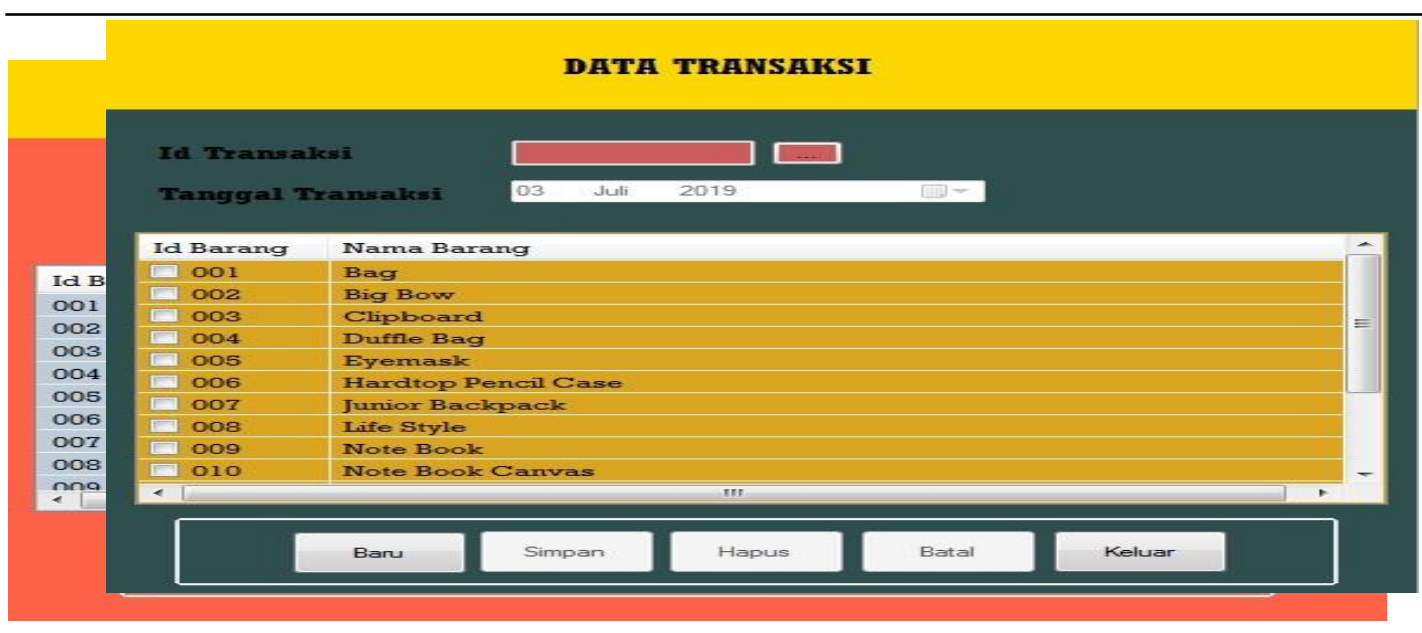

Gambar 4.3 Form Data Barang

4. Form Data Transaksi

Form Data Transaksi adalah Form yang digunakan untuk mengelola data penjualan peralatan sekolah pada Brand Wigglo. Berikut adalah tampilan Form Data Transaksi:

\section{Gambar 4.4 Form Data Transaksi}

5. Form Kobinasi Item

Form Kombinasi Item adalah Form yang digunakan untuk mengelola data penjualan peralatan sekolah pada Brand Wigglo. Berikut adalah tampilan Form Kombinasi Item:

\begin{tabular}{|c|c|c|c|c|c|}
\hline ID Transaksi & Nama Barang & ID Bar.. & Nama Barang & Quantity & - \\
\hline 1 & Clipboard,Note Book, Note Keyring, W.allet,Pencil Case,Pouch,Life Styl... & 001 & Bag & 19 & \\
\hline 2 & Note Keyring, Life Style, Sling Bag, & 002 & Big Bow & 4 & \\
\hline 3 & Note Book, Note Keyring,Pencil Case,Pouch,Bag, Note Book Canvas, & 003 & Clipboard & 21 & \\
\hline 4 & Clipboard,Note Book,Note Keyring, Wallet,Big Bow, & 004 & Duffle Bag & 6 & \\
\hline 5 & Note Keyring,Life Style,sling Bag, & 005 & Eyemask & 5 & $\equiv$ \\
\hline 6 & Note Book,Note Keyring,Pencil Case,Pouch,Bag,Sling Bag, & 006 & Hardtop Pencil Case & 10 & \\
\hline 7 & Clipboard,Note Book,Bag,Sling Bag,Eyemask, Hardtop Pencil Case, & 007 & Junior Backpack & 15 & \\
\hline 8 & Clipboard,Bag,Life Style, Sling Bag. Junior Backpack, & 008 & Life Style & 12 & \\
\hline 9 & Clipboard,Note Book,Note Keyring,Pencil Case,Pouch,Bag,sling Bag,J... & 009 & Note Book & 19 & \\
\hline 10 & Clipboard,Wallet,Pencil Case,Bag, Junior Backpack, Eyemask, & 010 & Note Book Canvas & 8 & \\
\hline 11 & Clipboard,Note Book,Note Keyring, Wallet,Pouch,Bag, life Style,Hardt... & 011 & Note Keyring & 14 & \\
\hline 12 & Note Boolk,Note Keyring,Pencil Case,Pouch,Bag,Junior Backpack, & 012 & Pencil Case & 17 & \\
\hline 13 & Duffle Bag,Hardtop Pencil Case, & \multirow{2}{*}{\multicolumn{4}{|c|}{ i }} \\
\hline 14 & Clipboard,Note Keyring, Big Bow, & & & & \\
\hline 15 & Life Style, Sling Bag, Hardtop Pencil Case, & \multirow{3}{*}{ Proses } & \multirow{3}{*}{ Support 2 item set } & \multirow{3}{*}{ Keluar } & \\
\hline 16 & Clipboard,Note Book,Pencil Case,Pouch,Bag,Eyemask,Note Book Can... - & & & & \\
\hline & III & & & & \\
\hline
\end{tabular}

J-SISKO TECH Vol. 3, No. 1, $2020: 118-136$ 
Gambar 4.5 Form Kombinasi Item

6. Form Proses Apriori

Form Proses Apriori adalah Form yang digunakan untuk menghitung nilai Support dan Confidance. Berikut adalah tampilan Form Proses Apriori:

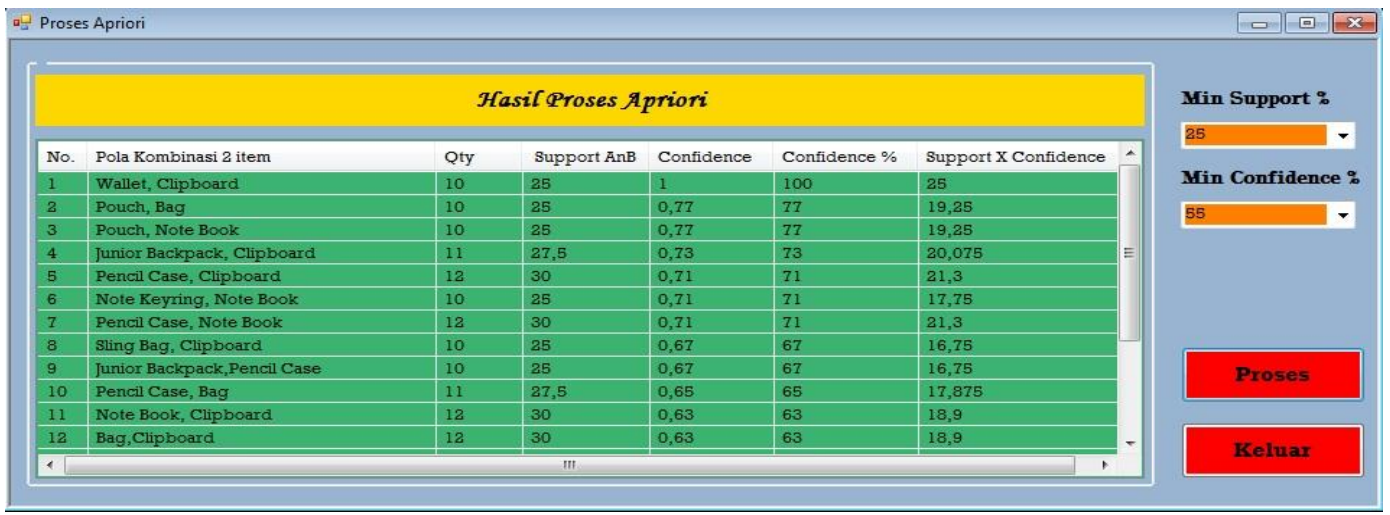

Gambar 4.6 Form Kombinasi Item

7. Form Laporan

Form Laporan adalah Form yang digunakan untuk mengetahui kombinasi diantara 2 item

PT. PANEN LESTARI INTERNUSA

Penerapan Data Mining Untuk Menentukan Pola Penjualan Peralatan Sekolah Pada Brand Wigglo Dengan Menggunakan Algoritma Apriori

\begin{tabular}{|c|c|c|c|}
\hline No & Pola & Qty & Persen \\
\hline $\begin{array}{l}2956 \\
2957 \\
2958 \\
2959 \\
2960 \\
2961 \\
2962 \\
2963 \\
2964 \\
2965 \\
2966 \\
2966 \\
2968 \\
2969 \\
2970 \\
2971 \\
2971 \\
2973\end{array}$ & $\begin{array}{l}\text { Bag,Clipboard } \\
\text { Bag,Pencil Case } \\
\text { Clipboard,Note Book } \\
\text { Clipboard,Pencil Case } \\
\text { Junior Backpack, Pencil Case } \\
\text { Note Book, Pencil Case } \\
\text { Clipboard, Bag } \\
\text { Pencil Case, Bag } \\
\text { Pouch, Bag } \\
\text { Junior Backpack, Clipboard } \\
\text { Note Book, Clipboard } \\
\text { Pencil Case, Clipboard } \\
\text { Sling Bag, Clipboard } \\
\text { Wallet, Clipboard } \\
\text { Pencil Case, Junior Backpack } \\
\text { Note Keyring, Note Book } \\
\text { Pencil Case, Note Book } \\
\text { Pouch, Note Book }\end{array}$ & $\begin{array}{l}12 \\
11 \\
12 \\
12 \\
10 \\
12 \\
12 \\
11 \\
10 \\
11 \\
12 \\
12 \\
10 \\
10 \\
10 \\
10 \\
12 \\
10\end{array}$ & $\begin{array}{l}63,00 \\
58,00 \\
57,00 \\
57,00 \\
67,00 \\
63,00 \\
57,00 \\
65,00 \\
77,00 \\
73,00 \\
63,00 \\
71,00 \\
67,00 \\
100,00 \\
59,00 \\
71,00 \\
71,00 \\
77,00\end{array}$ \\
\hline
\end{tabular}

Gambar 4.7 Form Laporan

\subsection{Pengujian}

Dalam tahap ini akan dilakukan uji coba terhadap aplikasi Data Mining dengan menggunakan Algoritma Apriori yang telah dibangun, Pengujian : 


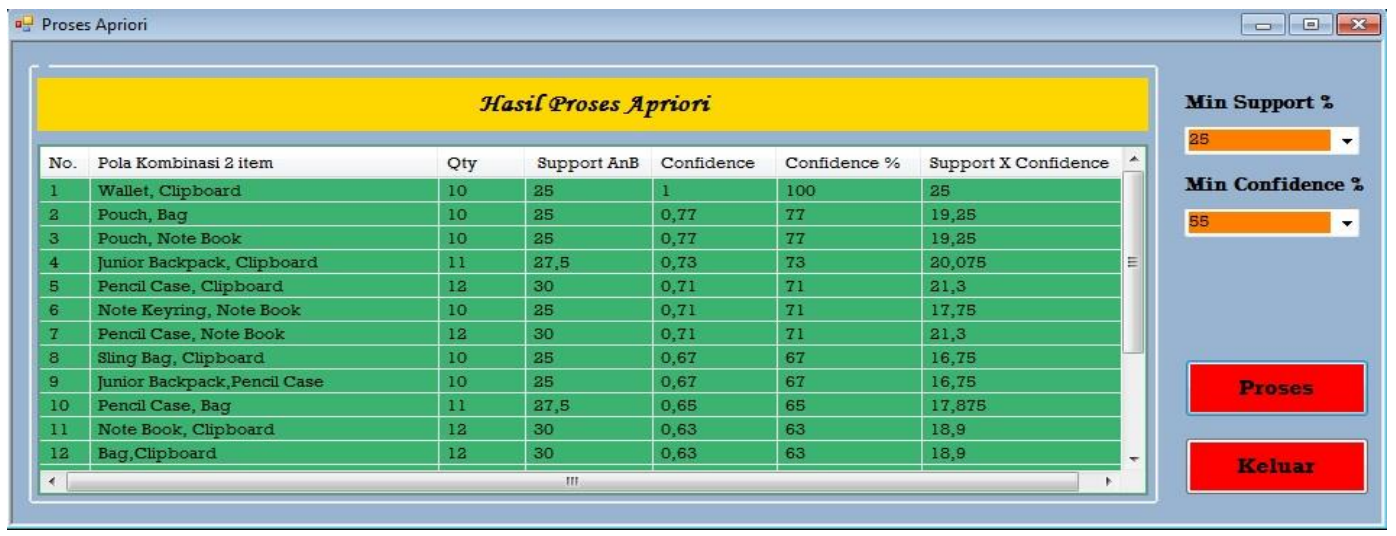

Gambar 4.8 Hasil Pengujian

\subsection{Kesimpulan}

Dari hasil perancangan aplikasi data mining dalam menentukan pola penjualan peralatan sekolah maka diperoleh suatu kesimpulan sebagai berikut:

1. Untuk menganalisa terhadap permasalahan yang terjadi maka dilakukan sebuah penelitian terhadap data-data penjualan peralatan sekolah yang ada pada PT. Panen Lestari Internusa serta melalukan wawancara terhadap perusaaahan PT. Panen Lestari Internusa.

2. Untuk membentuk pola kombinasi itemset maka dilakukan sebuah perhitungan terhadap data transaksi yang ada kemudian dilakukan pencarian nilai support dan nilai confidance setelah itu dilakukan membentuk pola kombinasi itemset .

3. Untuk merancang aplikasi data mining maka dibutuhkan beberapa perancangan diantaranya adalah perancangan sistem, perancangan database dan perancangan user interface untuk mengdapatkan hasil yang sesuai dengan yang diharapkan.

\section{UCAPAN TERIMA KASIH}

\section{REFERENSI}

[1]Andi, \& Madcoms. (2010). Seri Panduan Pemrograman Database Visual Basic dengan Crystal Report. Yogyakarta: Andi, \& Madiun: Madcoms.

[2]Hendrayudi. (2011). Dasar-Dasar Pemrograman: Microsoft Visual Basic 2008. Bandung: Satu Nusa.

[3]Jogiyanto, H.M. (2012). Analisis dan Desain. Yogyakarta: Andi Offset.

[4]Nofriansyah, D., \& Nurcahyo, G. W. (2015). Algoritma Data Mining dan Pengujian. Yogyakarta: Deepublish.

[5]Rosa, A.S., \& Shalahuddin, M. (2015). Rekayasa Perangkat Lunak: Terstruktur dan Berorientasi Objek. Bandung: Informatika.

[6]Ali Ikhwan, Dicky Nofriansyah, Sriani. (2011). "Penerapan Data Mining dengan Algoritma Apriori untuk Mendukung Strategi Promosi Pendidikan ( Studi Kasus Kampus STMIK Triguna Dharma)". Jurnal Saintikom, 13(3), 213.

[7]Ristianingrum, Sulastri,Implementasi Data Mining Menggunakan Algoritma Apriori, Jurnal Prosiding SINTAK 201, 372-382

[8]Ristianingrum, Sulastri,Implementasi Data Mining Menggunakan Algoritma Apriori, Jurnal Prosiding SINTAK 201, 372-382

[9]Yohanni Syahra, Yusnidah, Beni Andika, Penerapan Algoritma Fuzzy C-Means Dipadukan Dengan Model Fuzzy Recency Frequency Monetary (RFM) Untuk Costumer Relationship Management (CRM), Jurnal SAINTIKOM Vol. 15, No. 1, Mei 2016 